\title{
IPTEKS BAGI WILAYAH (IbW) DI KECAMATAN GEROKGAK
}

\author{
Oleh: \\ Ida Bagus Putu Mardana, dkk \\ Fakultas Matematika dan Ilmu Pengetahuan Alam \\ Universitas Pendidikan Ganesha
}

\begin{abstract}
ABSTRAK
Kegiatan IbW yang dilakukan pada tahun II (Tahun 2011) adalah melakukan pemetaan asset di wilayah garapan dan melaksanakan program ipteks peningkatan pengetahuan dan keterampilan dalam pertanian-peternakan-perikanan, pendidikan life skill dan kewirausahaan, dan pembinaan adat-istiadat, keagamaan, dan lembaga sosial. Metode pelaksanaan $\mathrm{I}_{\mathrm{B}} \mathrm{W}$ dalam pemberdayaan masyarakat miskin adalah metode PALS (participatory action learning system) yang bersendikan pada 3(tiga) tahapan kegiatan, yakni (1) tahap penyadaran (Awareness), (2) tahap pengkapasitasan/pendampingan (participating /scaffolding), dan (3) tahapan pelembagaan (institutionalization). Hasil kegiatan IbW pada tahun II (tahun 2011) adalah terwujudnya deplot setra industri pengolahan kelapa, demplot pertanian multikultur, demplot peternakan berbasis zero waste. Dampak yang ditimbulkan dari pelaksanaan program IbW tahun II adalah adanya peningkatan kesadaran masyarakat untuk meningkatkan kualitas hidup melalui pelipatgandaan aktivitas ekonomi produktif masyarakat berpijak pada potensi dan kearifan lokal yang ada, dan peningkatan penguasaan IPTEKS untuk meningkatkan kapasitas dan diversifikasi produksi hasil tani-ternak-perikanan.
\end{abstract}

Kata-kata kunci: pemberdayaan, KK miskin, PALS, potensi wilayah, IbW

\begin{abstract}
The main programme of IbW in the second year (the year of 2011) were asset mapped of the area, and implemented an action IBW in handling problems in dry land areas Gerokgak, namely the implemented of the science and technology program in order to increased knowledge and skills in agriculture-livestock-fishery, education, life skill and entrepreneurship, as well as quiding the socials customary, religious, and social institutions. The method of IbW in the empowering of community was the PALS method (participatory action learning system) that refer to 3 (three) stages, namely stage of awareness, stage of participating / scaffolding, and stages of institutionalization. The results of $\mathrm{IbW}$ in the first year was the installation of centre coconut processing industry, the multiculturalism agriculture demonstration and plots, the zero waste farm of demonstration and plots demonstration a. The installation of demomstration and plot was a mean of altering the mind-set of community in handling the live resources optimally. The impacts of IbW program were the existence of increasing public awareness to improve the quality of life through the multiplied of economic productive activities based on potential and existing local genuine, and the improving of community capability in science and technology to increase production capacity and diversification of the agricultural-livestock-fishery product process.
\end{abstract}

Key words: empowerment, poornes family, PALS, region potency, IbW 


\section{Pendahuluan}

Secara umum, kondisi eksisting kawasan $\mathrm{I}_{\mathrm{B}} \mathrm{W}$ yang meliputi desa Patas, desa Gerokgak, desa Musi, dan desa Sangalangit merupakan kawasan yang diproyeksikan menjadi kawasan industri perikanan, pertanian dan peternakan dalam arti luas untuk menunjang eknomi masyarakat. Keempat desa ini merupakan wilayah pantai dan perbukitan, yakni perpanduan antara laut dan pegunungan (nyegara-gunung) beriklim tropis, dengan curah hujan yang relatif sangat rendah. Keadaan tanahnya sebagian besar kering/tegalan yang hanya dapat ditanami tanaman hortikultura, palawija, perkebunan, dan beberapa diantaranya persawahan. Lapisan top soil tanah relatif sangat tipis dengan tingkat kesuburan yang terbatas, karena tanah bersifat poros, sehingga sulit menyimpan air. Namun demikian, budidaya pertanian dan peternakan masih bersifat tradisional, yang miskin dengan sentuhan ipteks. Pengembangan peternakan tradisional yang tidak ramah lingkungan, sering menimbukan persoalan sanitasi lingkungan dan sumber wabah penyakit. Padahal limbah pertanian dan peternakan, melalui penerapan ipteks dapat dirubah menjadi sumber pakan ternak, pupuk organik dan sumber energi bakar alternatif sehingga dapat meningkatkan kualitas hidup dan kemandirian masyarakat.

Solusi yang ditawarkan untuk menangani permasalahan wilayah sasaran $I_{B} W$ adalah melaksanakan program ipteks bagi wilayah, yakni: (1) melaksanakan program aksi inisiasi $\mathrm{IbW}$ dalam penanganan masalah di wilayah $\mathrm{I}_{\mathrm{B}} \mathrm{W}$, yakni: (a) program ipteks peningkatan pengetahuan dan keterampilan dalam dalam program pertanianpeternakan-perikanan terpadu melalui (b) pembuatan demplot pertanian multikultur, (c) demplot peternakan terpadu yang ramah lingkungan (zero waste), (c) pengembangan demplot sentra industri kecil berbasis kelapa, dan (d) pembuatan demplot budidaya tambak ikan bandeng, (e) Program ipteks peningkatan pengetahuan dan keterampilan managemen wirausaha, perkoperasian dan pemberdayaan ekonomi masyarakat dan revitalisasi UKM-UKM, pembinaan KK miskin, dan pemberantasan buta aksara, dan (f) pengolahan aneka makanan tradisional dan modern berbasis hasil pertanian, perkebunan, dan perikanan, serta (g) melakukan evaluasi dan refleksi komprehensif terhadap program aksi, sebagai dasar pertimbangan dalam menjaga sustainabilitas program $\mathrm{I}_{\mathrm{B}} \mathrm{W}$ di wilayah Gerokgak secara mandiri. 


\section{Metode Pelaksanaan IbW}

Metode pelaksanaan $\mathrm{I}_{\mathrm{B}} \mathrm{W}$ adalah metode PALS (participatory action learning system), yang dikembangkan oleh Linda Mayoux tahun 2000-1n ( Chambers, 2007). Metode PALS merupakan salah satu metode pemberdayaan dalam lingkup PLA (participatory learning and action). Metode pelaksanaan IbW dengan PALS merupakan metode pemberdayaan masyarakat dalam pembangunan kewilayahan dengan tahapan-tahapan kegiatan, yakni (1) tahap penyadaran (Awareness) merupakan tahap inisiasi untuk menyadarkan masyarakat agar memahami kondisi dan potensi wilayah, serta usaha produktif yang dapat dilakukan untuk meningkatkan taraf hidup, (2) tahap pengkapasitasan (participating/scaffolding) adalah tahap pelibatan partisipasi aktif dan pendampingan pada masyarakat untuk membangun, mengelola, dan membesarkan usaha produktifnya, salah satunya melalui pembanguan demplot dan (3) tahapan pelembagaan (institutionalization) adalah mewadahi usaha produktif masyarakat pada suatu kelompok institusi yang dapat memudahkan proses belajar, transfer IPTEKS, pemasaran, dan jaminan legalitas formal.

\section{Hasil dan Pembahasan}

Kegiatan IbW di kawasan lahan kering Gerokgak tahun 2011, diawali dengan sosialisasi secara vertikal dengan menghaturkan upacara permohonan ijin/permakluman (piuning) kehadapan Tuhan Yang Maha Esa yang berstana di Pura Desa masing-masing di desa Patas, Gerokgak, Sanggalangit dan Musi. Selanjutnya, sosialisasi juga dilakukan secara horizontal dengan masyarajat dengan menghadirkan aparat pemerintah di tingkat kecamatan, desa, adat, tokoh masyarakat dan ketua kelompok produktif-ekonomis masyarakat di kawasan lahan kering Gerokgak, baik melalui kegiatan tatap muka maupun dialog interaktif di RRI. Saat sosialisasi, beberapa respon masyarakat dalam menyikapi kegiatan IbW Gerokgak terungkap bahwa (1) IbW Gerokgak memberi manfaat yang baik dalam mendampingi masyarakat program pembangunan, khususnya terkait dengan aktivitas tani-ternak, (2) masyarakat terobsesi untuk mengembangkan kawasan mandiri energi yang berbasis pada pengolaham limbah tani-ternak, dan (3) Program IbW hendaknya tersosialisasi sampai ke lapisan masyarakat bawah.

Program ipteks peningkatan pengetahuan dan keterampilan dalam diversifikasi produk pengolahan kelapa menjadi produk berorientasi pasar dilakukan dengan 
pengembangan demplot sentra industri kecil berbasis kelapa di 4(empat) desa sasaran IbW. Pada kegiatan IbW tahun pertama, pengelolaan demplot pengolahan kelapa ini ditangani oleh Ibu-ibu rumah tangga yang terkabung dalam Kelompok Wanita Tani (KWT), yang dinaungi oleh 4(empat) poktan yakni: poktan Patas, Poktan wanasari, poktan harapan kita, dan poktan Musi. Pada tahun 2011 (tahun kedua IbW) ini, penyadaran dan pengkapasitasan dilakukan pada semua anggota kelompok dalam usaha produktif berbasis kelapa dilakukan dengan pengembangan demplot centra pengolahan kelapa, yang diselenggarakan di empat desa, yakni desa Patas, Gerokgak, Sanggalangit, dan desa Musi. Setiap demplot yang ada di masing-masing desa dibantu hibah IbW berupa peralatan mesin pengolah daging kelapa "three in one", yakni parut, peras, dan saring, yang diproduksi oleh unit "UJI" Universitas Mahasaraswati Denpasar.

Dengan bantuan IPTEKS, tanaman kelapa dapat ditingkatkan pemanfaatannya baik dari segi pemanfaatan langsung, dikonsumsi atau diolah menjadi minyak goreng, batangnya untuk bangunan rumah/mobiler, bahan bakar untuk industri kapur, genteng serta gerabah, maupun dari segi pengolahan dengan sentuhan teknologi modern untuk menghasilkan produk-produk berorientasi ekspor. Secara utuh buah kelapa terdiri dari (1) bagian luar, adalah sabut kelapa dan tempurung kelapa, (2) daging kelapa, dan (3) air kelapa. Sabut kelapa dapat dipilah menjadi dua komponen yaitu serabut dan serbuk (cocodust). Serabut dapat digunakan untuk bahan jok mobil, tali, keset dan kerajinan yang lainnya, sedangkan serbuknya dapat dipergunakan untuk media tanam tanaman hias. Tempurung kelapa digunakan sebagai arang dan untuk bahan bakar produksi tanah liat. Dengan cara yang lebih modern tempurung kelapa dapat diolah menjadi briket sebagai bahan bakar untuk memaksa, menjadi karbon hita dan karbon aktif, sedangkan asap pembakaran tempurung kelapa dapat diolah menjadi liquid smoke sebagai bahan pengawet ikan. Secara keseluruhan, proses pengolahan kelapa dan produk turunannya. Daging kelapa dapat digunakan dalam pembuatan minyak dan VCO, santan, dan blondo. Sementara itu, air kelapa dapat diolah menjadi kecap dan sirup sari kelapa.

Partisipasi anggota Kelompok Wanita Tani (KWT) dan anggota poktan dalam kegiatan usaha produktif pengolahan kelapa sangat tinggi, hal ini dapat dilihat dari intensitas kehadiran, dan kuantitas dan kualitas persoalan/pertanyaan yang disampaikan terkait dengan pembuatan minyak kelapa VCO dan minyak lentik/minyak tradisional. Hasil pemberdayaan poktan dalam usaha produktif berbasis 
kelapa adalah (1) adanya peningkatan kompetensi dalam pengolahan kelapa, khususnya dari minyak tradisional menjadi VCO, (2) menghasilkan kualitas produk minyak tradisional/VCO yang lebih baik, (3) meningkatkan kapasitas produksi pengolahan kelapa menjadi minyak/VCO, (4) mendorong proses transformasi IPTEKS dalam penggunaan peralatan mesin pengolahan kelapa "three in one"bantuan IbW kepada kelompok poktak di masing-masing desa, dan (5) usaha produktif berbasis kelapa ini akan mendorong kelompok untuk membentuk koperasi usaha kelapa yang menjadi unggulan komoditas ekonomi desa di wialaya garapan IbK Gerokgak.

Selain membina usaha produktif kelapa di setiap demplot yang ada di setiap desa kawasan IbW Gerokgak, Kegiatan program IbW lahan kering di Kecamatan Gerokgak pada tahun kedua (tahun 2011) juga membina usaha kecil dan menengah berbasis kelapa yang ada di kawasan itu dalam rangka meningkatkan pengetahuan dan keterampilan managemen wirausaha, perkoperasian dan pemberdayaan ekonomi masyarakat dan revitalisasi UKM difokuskan pada UKM pengolahan kelapa menjadi minyak tradisional, managemen usaha, dan pemasaran yakni UKM Minyak kelapa tradisional "mangga dua", yang dikomandani oleh Pak Made Yuliartha. UKM kelapa ini termasuk industri kecil skala rumah tangga. Pada tahun kegiatan 2011 ini, UKM "mangga dua" dibina dalam aspek managemen pembukuan dan pemasaran, selain program pendampingan dalam peningkatan kapasitas produksi dan diversifikasi produk olahan kelapa.

Minyak lentik (tradisional) yang diproduksi UKM minyak mangga dua, awalnya masih menggunakan teknologi tradisional, baik dalam cara pengolahan, maupun peralatan produksi yang digunakan belum mampu mendatangkan keuntungan yang maksimal. Peningkatan pengetahuan dan keterampilan UKM dalam pengolahan kelapa menjadi minyak lentik secara modern dengan memanfaat ektrak kimia dalam mempercepat produksi dan penggunaan mesin parut "three in one" yang dihibahkan IbW kepada UKM telah mampu meningkatkan kualitas dan kuantitas produksi minyak lentik yang dihasilkan oleh UKM minyak mangga dua di desa Sanggalangit. Usaha industri kecil minyak kelapa ini juga dieskalasi pemberdayaannya di setiap demplot yang ada di wilayah IbW Gerokgak, yakni desa Patas, desa Gerokgak, desa Sanggalangit, dan desa Musi. Masing-masing demplot pada pelaksanaan IbW Gerokgak tahun kedua ini telah dihibahkan masing-masing mesin parut kelapa three in one", dengan harapan ada kegiatan produksi minyak kelapa di setiap demplot. 
Proses pemanasan produksi minyak lentik di demplot menggunakan kompor biogas hasil pengolahan limbah ternak.

Wilayah sasaran IbW lahan kering Gerokgak menghasilkan produk pertanian, perkebunan, dan perikanan yang berlimpah saat musim panen. Akibat rendahnya penguasaan kompetensi dalam pengolahan hasil pertanian/perkebunan sering panen yang berlimpah belum mampu memberi kontribusi ekonomis dalam mendongkrak penghasilan keluarga. Pengolahan aneka makanan tradisional dan modern berbasis hasil pertanian melalui pelatihan dan pendampingan produksi, managemen, dan pemasaran merupakan upaya solutif yang dapat dikedepankan dalam membantu masyarakat sasaran IbW untuk meningkatkan taraf hidupnya. Aktivitas IbW dalam konteks ini pada tahun 2011 adalah pelatihan pengolahan pisang Gerokgak menjadi produk (1) sele pisang, (2) sale pisang, (3) keripik pisang, (4) pisang goreng, (5) sumping, (6) kolek pisang, dan (7) produksi jamu kunir. Masyarakat sasaran adalah kelompok PKK di empat desa wilaya IbW di kecamatan gerokgak. Penyadaran dan pengkapasitasan kelompok PKK dilakukan melalui pelatihan dan pendampingan produksi, dan pemasaran.

Keterbatasan yang dimiliki lahan kering cenderung membuat kegiatan pola usahatani bersifat subsistem (tradisional). Pola usahatani tanaman semusim yang biasanya dilakukan di lahan kering adalah pola usahatani tanaman pangan seperti jagung, kacang tanah dan jenis palawija lainnya. Pola usahatani tanaman pangan dilakukan pada musim penghujan menggunakan teknologi sederhana dengan varietas lokal sehingga hasilnya rendah. Selain itu pemeliharaan ternak (umumnya sapi) masih tradisional dan monokultur sehingga produktivitasnya rendah. Pemberdayaan masyarakat di kawasan lahan kering di kecamatan Gerokgak pada program IbW tahun kedua ini dilakukan dengan pencanangan program aksi pertanian-peternakan multikultur, sesuai dengan diskusi mendalam dengan masyarakat di 4(empat) desa dengan merefleksi hasil kegiatan IbW tahun pertama (tahun 2010), yakni desa Patas, Gerokgak, Sanggalangit dan desa Musi, melalui pembuatan demplot tani-ternak multikultur .

Sampai tahun kedua (tahun 2011) pelaksanaan IbW Gerokgak, telah berhasil menginstal 4(empat) unit demplot tani-ternak multikultur, yakni di desa Patas, desa Gerokgak, desa Sanggalangit, dan desa Musi. Infrastruktur fisik yang dibangun IbW Gerokgak pada setiap demplot adalah (1) unit kandang koloni sapi, kandang koloni babi dan kandang koloni ayam, (2) unit pengolahan limbah biogas dan biourine, (3) 
unit produksi pembuatan kompos dan minyak kelapa, (4) unit kolam ternak lele, dan (5) tanaman multikultur, meliputi tanaman pakan ternak dan tanaman tumpang sari. Ketahanan ekonomi masyarakat yang banyak bertumpu dari hasil ternak-tani disikapi dengan mengembangkan ternak multikultur,yakni ternak sapi sebagai penghasil income tahunan, ternak babi sebagai penghasil income enan bulan, dan ayam merupakan sumber penghasilan masyarakat bulanan. Hal yang sama juga pada aspek pertanian, dimana masyarakat di setiap demplot sebagai episentrum aktivitas pemberdayaan, dikapasitaskan untuk menanam tananman yang dapat memenuhi kebutuhan konsumtif jangka pendek sampai jangka panjang.

Model pertanian-peternakan terpadu merupakan aktivitas produktif pertanianpeternakan dalam satu siklus berantai, yakni pemanfaatan limbah tanaman pada budidaya tani untuk pakan ternak. Demikian juga sebaliknya budidaya ternak, limbah ternak dapat dimanfaatkan untuk pertanian. Sebagai langkah awal diintroduksikan penanaman rumput raja dan gamal di pematang petakan lahan petani untuk menambah penyediaan hijauan pakan ternak selain itu juga diperkenalkan perkandangan menetap, dan pengawetan pakan ternak. Selanjutnya juga diintroduksikan pemanfaatan air embung untuk pertanaman sayuran (bawang merah, semangka, kacang panjang dan bawang putih) yang memiliki nilai ekonomis tinggi. Secara diagramatik, program aksi usaha produktif peternakan-pertanian terpadu melalui demplot pertanian multikultur dan peternakan, perikanan terpadu.

Program aksi usaha produktif pertanian-peternakan-perikanan terpadu diawali introduksi teknologi pemanfaatan limbah tanaman untuk pakan ternak serta pemakaian limbah ternak ke pertanaman, pemeliharaan ternak sapi/babi secara intensif. (1) Langkah awal mengintroduksikan model perkandangan menetap dan penanaman rumput raja dan gamal di pematang petakan lahan untuk penyediaan hijauan pakan ternak, dimana demplot tani-ternak terpadu akan dibangun di masingmasing desa. (2) mengintroduksikan diversifikasi penanaman sumber hayati baik di pekarangan rumah, lahan tegalan kosong, dan sekitar demplot tani-ternak terpadu. Setiap anggota kelompok tani (Poktan) diminta untuk menanam dan merawat satu pohon pisang. (3) mengintroduksi pemanfaatan embung air dalam pemenuhan kebutuhan air di musim kering.

Hasil pemberdayaan masyarakat yang terkabung kelompok tani (poktan) dalam usaha produktif pertanian multikultur dan peternakan ternak sapi/babi terpadu adalah (1) adanya peningkatan kompetensi bertani multikultur dalam intensifikasi budi daya 
ternak sapi/babi/ayamayam terpadu, menuju usaha produktif yang zero waste, (2) mendorong proses transformasi IPTEKS dalam pengolahan limbah ternak sapi/babi/unggas menjadi pupuk dan bio-gas, (5) adanya peningkatan investasi kekompok tani dalam bentuk jumlah bibit ternak sapi/babi/ayam modal yang diberikan pada program IbW di masing-masing desa. Semua aktivitas produktif ekonomi yang berlangsung di poktan berlangsung dengan baik karena IbW Gerokgak telah memfasilitasi ketersediaan listrik PLN 1300 watt, 220 volt, sehinggan semua peralatan produksi dapat bekerja dengan baik, biogas untuk bahan bakar alternatif dan embung reservoar air untuk keperluan tani-ternak dan kebutuhan air sehari-hari.

Pola peternakan tradisional non-koloni yang berkembang di masyarakat wilayah IbW, kurang memperhatikan sanitasi lingkungan. Peternakan non-koloni sering menjadi sumber pencemaran lingkungan yang mengancam kesehatan masyarakat dan keasrian lingkungan hidup di sekitarnya. Masyarakat secara berjenjang perlu dibudayakan beternak terpadu yang ramah lingkungan (zero waste) melalui pembuatan demplot peternakan terpadu yang dilengkapi dengan sistem pengolahan limbah menjadi sumber energi alternatif biogas sebagai energi alternatif bahan bakar, bio-urine dan pupuk organik (kompos) untuk bio-fertilizer pertanian.

Program inisiasi IbW pembudayaan masyarakat lahan kering gerokgak pada tahun kedua 2011 dalam peternakan terpadu ramah lingkungan dilakukan dengan pembuatan demplot peternakan terpadu zero waste pada kelompok tani-ternak Renon Asri di desa Gerokgak, dan kelompok tani-ternak harapan kita di desa Sanggalangit seperti ditunjukkan pada gambar 6. Selain membangun sistem pengolahan limbah, poktan juga diberi bantuan sapi, babi dan ayam untuk meningkatan modal kerja poktan. Pemanfaatan biogas di demplot lebih banyak digunakan untuk energi bahan bakar alternatif untuk usaha produkti ekonomi minyak kelapa, sehingga dapat menekan biaya produksi untuk membeli minyak tanah. Disamping itu, pemanfaatan pengolahan limbah ternak dalam bentuk biogas ini juga disosialisasi di tingkat keluarga. Setiap keluarga yang memiliki 2 ekor ternak sapi, juga diberdayakan untuk membangun unit reaktor biogas untuk memenuhi kebutuhan bahan bakar sehari-hari. Pada tahun 2011 ini, IbW Gerokgak sudah berhasil menginstal 20 unit biogas di tingkat keluarga tersebar di wilayah garapan IbW Gerokgak.

Mengingat kecamatan Gerokgak merupakan wilayah penyumbang tertinggi angka buta aksara/putus sekolah, maka secara bertahap program IbW Gerokgak mencanangkan pendidikan keaksaraan bagi masyarakat buta huruf/putus sekolah 
melalui pendidikan life skill/keaksaraan dengan model pendidikan kelompok kelas kecil di empat desa wilayah sasaran IbW, yakni desa Patas, desa Gerokgak, desa Sanggalangit, dan desa Musi. Jumlah anggota kelompok masyarakat belajar di setiap desa bervariasi 10-15 orang. Tutor kelompok belajar diambil dari mahasiswa KKN dan anggota masyarakat setempat yang berkompeten diberdayakan untuk mendampingi kegiatan belajar dan mengajar. Kegiatan belajar secara formal dilakukan melalui tatap muka, tetapi juga disuplemen dengan aktivitas kontekstual dalam proses pembelajaran melalui kegiatan-kegiatan produktif ekonomi dan pendidikan life skill, seperti pembuatan makanan tradisional dan pengolahan ikan.

Terdapat 2302 KK miskin yang tersebar di kecamatan Gerokgak, termasuk di empat desa wilayah sasaran IbW. Pola kemiskinan struktural yang terjadi di wilayah ini, perlu penanganan yang terpadu sehingga KK miskin dapat meningkatkan kualitas hidupnya. Program yang dicanangkan IbW dalam konteks penanganan KK miskin adalah pemberdayaan KK miskin melalui program simantri ( sistem pertanianpeternakan terintegrasi) dalam skala rumah tangga. Masing-masing desa di wilayah IbW Gerokgak diambil 10 KK miskin sebagai keluarga binaan IbW. Aktivitas inisiasi yang dilakukan di setiap keluarga miskin adalah (1) mengintroduksi perternakan dengan sistem kandang, (2) pemberian bantuan bibit babi, (3) menginstall biogas skala rumah tangga, dan (4) penanaman bibit pakan ternak dan pangan di halaman rumah, (5) program tanam satu pohon pisang di halaman rumah, (6) pelayanan kesehatan gratis.

Sesuai dengan permintaan masyarakat dan pemetaan analisis kebutuhan terhadap aktivitas keagamaan dan sosial masyarakat wilayah sasaran IbW Gerokgak, makan penghijauan dilakukan dengan (1) penanaman bibit pohon jati kamelina. Pohon jati kamelina, di satu sisi dapat berfungsi sebagai tanaman konservasi/penghijauan, namun juga dimanfaatkan sebagai pakan ternak oleh masyarakat, sehinggan dapat mengurangi beban hutan yang sering menjadi sasaran pengrusakan masyarakat miskin dalam pemenuhan pakan ternak dan kayu bakar; dan (2) penanaman bibit pohon kelapa varietas lokal Bali, untuk pemenuhan tingginya tuntutan upacara keagamaan baik vertikal maupun horizontal akan kebutuhan kelapa lokal Bali. Pengadaan bibit tanaman untuk penghijauan, pada tahun 2011 ini , IbW Gerokgak telah mendorong poktan untuk membuat pembibitan tanaman lokal tradisional Bali untuk item tanaman konservasi hutan di kawasan Gerokgak. 
Selain program konservasi hutan untuk meningkatkan kemampuan hutan untuk menampung air, sehingga menekan ancaman kekeringan di wilayah Gerokgak, juga dilakukan perawatan dan penataan sumber-sumber air yang sudah ada, baik pemanfaatnnya secara horizontal maupun vertikal. Keyakinan masyarakat akan tersedia dan terjaganya sumber air di beberapa kawasan lahan kering di wilayah Gerogak merupakan anugerah dari Tuhan Yang Maha Esa yang perlu dijaga dan disucikan, maka dari itu atas kesepakatan warga masyarakat, pemkab, dan tokoh agama/adat dalam program $\mathrm{IbW}$ ini membangun tempat pura Beji, sebagai tempat penginstanaan kesucian air/ dan pemujaan dewa air dalam menjaga/mencegah kawasan gerokgak dari ancaman kekeringan seperti ditunjukkan pada gambar 9. Pura Beji ini juga sekaligus difungsikan sebagai media perekat ikatan sosial masyarakat dalam pemanfaat air baik bagi pertanian, peternakan, dan pemenuhan kebutuhan hidup sehari-hari. Pada tahun 2011 ini IbW Gerokgak juga memfasilitasi masyarakat Gerokgak untuk membangun pura Panca Tirta sebagai situs spiritual masyarakat dalam pengelolaan sumber mata air yang ada di Pegunungan Gerokgak. Situs pura Panca Tirta ini akan berfungsi sebagai media religius dan sosial dalam menjaga keutuhan dan harmonisasi masyarakat sekitarnya.

\section{Penutup}

Dari paparan hasil dan pembahan diatas, maka dapat ditarik kesimpulan sebagai berikut. (1) profil potensi wilayah IbW di kecamatan Gerokgak, yakni desa Patas, desa Gerokgak, desa Sanggalangit, dan desa Musi menunjukkan daya dukung lahan yang cukup luas, dan potensi pertanian-peternakan-perikanan yang cukup tinggi. Lahan yang digunakan untuk pengembangan usaha dalam bidang pertanian dalam arti luas, sebagian besar adalah lahan kering. (2) Program inisiasi IbW pada tahun II (Tahun 2011) telah berhasil membangun (1) demplot pengolahan kelapa, demplot pertanian multikultur, (2) demplot peternakan berbasis zero waste, (3) demplot budidaya tambak hatchery-nursery ikan bandeng. (3) Dampak yang ditimbulkan dari pelaksanaan program inisisasi IbW, yakni (a) peningkatkan kesadaran masyarakat untuk meningkatkan kualitas hidup melalui aktivitas ekonomi yang produktif berpijak pada potensi dan kearifan lokal yang ada, (b) peningkatan penguasaan IPTEKS untuk meningkatkan kapasitas dan diversifikasi produksi hasil tani-ternak, (c) peningkatan investasi ekonomi KK miskin dalam bentuk mesin kelapa, bibit, modal, dan (d) peningkatan pendapatan (income) KK miskin. 


\section{DAFTAR PUSTAKA}

Beebe, James. Basic Concepts and Techniques of Rapid Appraisal. Human Organization, vol. 54, No. 1, Spring 1995.

BPS, 1998. Crisis Poverty and Human Development in Indonesia. BPS. UNDP, Jakarta

Emil Salim. 1980. Perencanaan Pembangunan dan Pemerataan Pendapatan. Jakarta Yayasan Idayu.

Friedman, John, 1992, Empowerment : The Politics of Alternative Development. Blackwell Publishers, Cambridge, USA

Irawan, P.B. dan Romdiati. H, 2000. The Impact of Economic Crisis on Povertyand its Implication for Development Strategies, Paper Presented at National Workshop on Food and Nutrition VII. LIPI, 29 Febuari - 2 Maret 2000, Jakarta

Kartasasmita, Ginandjar. 1995. Pemberdayaan Masyarakat: Sebuah Tinjauan Administrasi; Pidato Pengukuhan Jabatan Guru Besar dalam Ilmu Administrasi pada Fakultas Ilmu Administrasi Pemangunan Universitas Brawijaya; Malang. 1995. 